\title{
NEW LOCALITIES AND HABITAT CONDITIONS FOR CHOIROMYCES MEANDRIFORMIS VITT. (ASCOMYCOTA, FUNGI) IN NORTHERN ROMANIA
}

\author{
Ciprian BÎRSAN $^{1 *}$, Constantin MARDARI ${ }^{1}$, Cătălin TĂNASE ${ }^{2}$ \\ 1 “Anastasie Fătu” Botanical Garden, “Alexandru Ioan Cuza” University, 7-9 Dumbrava Roșie, \\ 700487 Iași - Romania \\ ${ }^{2}$ Faculty of Biology, "Alexandru Ioan Cuza” University of Iaşi, Carol I 20A, 700505 Iaşi - Romania \\ *Corresponding author. E-mail: ciprian.birsan@uaic.ro
}

\begin{abstract}
Although Choiromyces meandriformis is considered as a wide-spread fungus species in forest habitats of Europe, still it is listed as rare, endangered and even critically threatened in some countries. In Romania the species is sporadically spread throughout the Carpathian Mountains and surrounding areas, in soils under both deciduous and coniferous species. In this study there are presented two new localities for Choiromyces meandriformis in northern part of Romania, where the species was identified in spruce communities. The specimens were macroscopically and microscopically characterized and soil analyses were performed. Also, a phytosociological investigation of the forest habitat was performed. Soil analysis highlighted the species preference for acidic soils, with a medium content of humus, total nitrogen, potassium and total phosphorus, and a reduced amount of organic matter. The forest community (Hieracio transsivanici-Piceetum) was characterized by a uniform and species-poor floristic composition.
\end{abstract}

Keywords: Choiromyces meandriformis, ecology, habitat, soil characteristics, hypogeous fungi.

\section{Introduction}

Choiromyces meandriformis is a hypogeous fungal species, wide-spread in Europe, from the UK in the western part of the continent to the extreme east of Russia, from Sweden in the north, to Spain, Italy and Greece to the south. Etymology of name derives from the Greek words choiros $=$ pig + mykes $=$ mushroom $($ porcine truffle) and Latin maeander $=$ meander, sinuous river + formis [BRESSON, 1996]. The genus Choiromyces is characterized by hypogeal, sub-globular or irregular shaped sporocarps. Their gleba is solid and has visible veins. The asci are indehiscent, clavated, with 8 spores, and no reactivity to the Melzer reagent. The spores are usually globose, hyaline or yellow-brown and ornamented with thorns, pits, or alveolated cross-links. The species Choiromyces meandriformis is collected and consumed as a delicacy in Sweden [WEDEN \& al. 2009]. Despite its economic importance, limited information on this fungal genus diversity and distribution is available worldwide. Based on the morphologic similarity, some species within the Choiromyces genus may be confused with species of the Tuber genus on the market. Thus, some species of Choiromyces (e.g. C. meandriformis) may be sold as T. magnatum Picco, a highly edible species of the Tuber genus on European markets for the uninitiated people [MORENO \& al. 2012].

Choiromyces meandriformis occasionally occurs under duglas, pines and under Tsuga at low altitudes, being slightly widespread in North America (and common in Europe) 
[BEUG \& al. 2014]. It is apparently a relative common species of truffle and appears to be widespread in the United Kingdom [HOBART, 2005]. In Italy, collected data over the last decade regarding the ecology and distribution of hypogean and semi-hypogean fungi allowed the assessment of their status, and species within Choiromyces sp. were considered rare [VENTURELLA \& al. 2011]. Also, in Poland, it is a considered a rare species [HALAMA $\&$ PANEK, 2000], that produces sporocarps at the end of summer and in autumn and occur in mixed oak and beech forests. In France, it is also encountered during the summer season, being one of the largest hypogean mushrooms in the country, which often produces cracks in the soil, thus being easily identified [FOURRÉ, 2000]. In Spain, it has been identified in the Basque Country [CALONGE \& al. 1977] and in Navarra at higher elevation (c.a. $1200 \mathrm{~m}$ a.s.1.) under Picea abies trees [SIERRA \& al. 1991]. In Lithuania, the species was found in the vicinity of hardwoods (oaks, birch, alder and willow), in mixed and coniferous forests, from August to October [KUTORGA \& KATARŽYTE், 2008]. Some localities (Izmir, Uşak, Bolu, and Samsun) have been reported from Turkey [TÜRKOĞLU \& CASTELLANO, 2014]. In Bulgaria is included in the Red List of Fungi [GYOSHEVA \& al. 2006] as endangered (EN) species. It is also included in the Red Book of Lithuania (2007) as endangered [KUTORGA \& KATARŽYTE், 2008].

In Romania, Choiromyces meandriformis is encountered from July to September [SĂLĂGEANU \& SĂLĂGEANU, 1985]. The species is widespread throughout the Carpathian Mountains and surrounding regions, and can be identified in soils under both deciduous and coniferous species. Comprehensive information on distribution of hypogeal fungi in Transylvania (and Harghita County in particular) was published in the work of PAP $\&$ al. (1983). Also, according to PAZMANY (1990) Choiromyces meandriformis is found in Alba County (Zlatna), Caras-Severin County (Anina, Băile-Herculane and Moldova Nouă), Cluj County (Cluj-Napoca and surrounding areas), Covasna County (Sânzieni and Ojdola), Harghita County (Gheorgheni, in forests dominated by fir, Borsec, Ditrău, Mihăileni, Topliţa, Rugăneşti, Cristuru-Secuiesc), Maramureş County (Ocna-Şugatag, in areas dominated by oak and Maramureş depression), Salaj County (Romanaşi). It was also identified in Sibiu County, in Tufa Mohului Forest [NEGREAN \& DRĂGULESCU, 2005].

The main objective of this article was to present new localities where the species was identified and to characterize the habitat in respect to soil properties and forest characteristics.

\section{Material and methods}

The specimens were identified based on the analysis of macroscopic and microscopic characters, using literature: GERHARDT (1999), SĂLĂGEANU (1985), ASTIER (1998), COURTECUISSE \& DUHEM (2013), TRAPPE \& CASTELLANO (2007). The nomenclature followed Index Fungorum [http://www.indexfungorum.org/Names/Names.asp]. The soil analyses were performed at The Offices of Pedological and Agrochemical Studies (OSPA) Iaşi. The trees age was estimated according to the diameter and the forest documents. In order to characterize the floristic composition of habitats, phytosociological relevés have been performed according to the method of the Central European School for the study of vegetation [BRAUN-BLANQUET, 1964; BORZA \& BOŞCAIU, 1965]. 


\section{Results and discussions}

In this study are presented two new localities for Choiromyces meandriformis from northern part of Romania (Suceava County), where the species was identified in spruce young forests (Picea abies), in the first half of July 2013 and 2014 (Figure 1). The first spruce community was situated near Capu Câmpului village $\left(47^{\circ} 30^{\prime} 48.42^{\prime}\right.$ N, $\left.25^{\circ} 57^{\prime} 18.73^{\prime \prime E}\right)$ at approximately $500 \mathrm{~m}$ a.s.l., on a terrain with an inclination of $3-5^{\circ}$, eastern aspect, and had trees cover of c.a. 90\%. The second point was near Izvoarele Sucevei locality $\left(47^{\circ} 43^{\prime} 53.52^{\prime \prime} \mathrm{N}\right.$ and $\left.25^{\circ} 08^{\prime} 49.16^{\prime \prime} \mathrm{E}\right)$, at $1050 \mathrm{~m}$ a.s.1., in a terrain of $7-10^{\circ}$ inclination with northwestern aspect. The specimens of porcine truffle have been identified close/under to the spruce trees. The investigated truffle species has an important scientific and practically role because of their importance in mycorrhizal associations with different tree species. At the establishment of spruce plantation, seedlings were brought together with this porcine truffle. Later, after a certain number of years, it produced sporocarps which emerged to soil surface through the soil cracks under favorable conditions of development.



Figure 1. Map indicating the new localities for Choiromyces meandriformis in Northern region of Romania

The spruce forest from Capu Câmpului was about 40 years old, while the spruce forest at Izvoarele Sucevei area was approx. 50 years old.

The sporocarp was white at the beginning, then its colour became light yellowbrown, with a scented smell. Peridia was thin, smooth, often cracked. The gleba was fleshy, soft, white at first, and then marbled in yellow-brown by sinuous bands of pedunculated axes arranged in palisades (Figure 2). They were found in soil, under coniferous trees, in JulySeptember period. In Bulgaria it was also found at the beginning of October, in soil, in habitats with Picea abies and Abies alba in the Rhodope Mountains [LACHEVA, 2012]. 
The favourable conditions for this species in Northern Romania were represented by the temperate climate, more humid during all seasons, soil characteristics and vegetation type (forest vegetation with Picea abies in different age stages). Soil analysis (Table 1) highlighted the species' preference for acidic soils ( $\mathrm{pH}$ 5.06), with a medium content of humus, total nitrogen, potassium and total phosphorus, and a reduced amount of organic matter. These results in agreement (acid soil, wet site, spruce forest) with RODRIGEZ'S (2008) findings who identified the species (in Spain) also in acid and clay soils, in areas with increased rainfall, forming mycorrhizae with common oak (Quercus robur L.) and spruce (Picea abies).



Figure 2. Macroscopic aspect of analyzed specimens of Choiromyces meandriformis (Photo C. Bîrsan)

Table 1. Results of chemical analysis of soil samples collected in plots with Choiromyces meandriformis

\begin{tabular}{lcccc}
\hline & Soil characteristic & Value & U/M & Evaluation \\
\hline 1. & $\mathrm{pH}$ & 5,06 & - & Acid soil \\
\hline 2. & Humus & 2,89 & $\%$ & Middle \\
\hline 3. & Total Nitrogen & 0,126 & $\%$ & Middle \\
\hline 4. & Phosphorus & 46,0 & $\mathrm{ppm}$ & Good \\
\hline 5. & Accessible Potassium & 83,0 & $\mathrm{ppm}$ & Middle \\
\hline 6. & $\begin{array}{c}\text { Total Phosphorus } \\
\left(\mathrm{P}_{2} \mathrm{O}_{5}\right)\end{array}$ & 0,205 & $\%$ & Middle \\
\hline
\end{tabular}


Ciprian BîRSAN \& al.

\begin{tabular}{lcccc}
\hline 7. & $\begin{array}{c}\text { Total Potassium } \\
\left(\mathrm{K}_{2} \mathrm{O}\right)\end{array}$ & 0,187 & $\%$ & Middle \\
\hline 8. & Organic Matter & 5,70 & $\%$ & Reduced \\
\hline 9. & Total Zinc & 52,0 & $\mathrm{mg} / \mathrm{kg}$ & Max. val. 2000 \\
\hline 10. & Total Copper & 19,15 & $\mathrm{mg} / \mathrm{kg}$ & Max.val. 500 \\
\hline 11. & Total Lead & 26,0 & $\mathrm{mg} / \mathrm{kg}$ & Max.val. 300 \\
\hline 12. & Total Iron & 956,0 & $\mathrm{mg} / \mathrm{kg}$ & - \\
\hline
\end{tabular}

The forest habitat (Figure 3) was characterized by a uniform and species-poor floristic composition, typical to Hieracio transsivanici-Piceetum Pawl. et Br.-Bl. 1939 community (Table 2). Trees layer presented high cover (90\%) and was dominated by Picea abies while Sorbus aucuparia, Fagus sylvatica, Betula pendula, Acer pseudoplatanus were sporadically identified. The shrubs layer (with Corylus avellana and Spiraea chamaedryfolia) had very low cover (3-5\%). Herbs layer was also species-poor, and had low cover (2-10\%) with Luzula luzuloides, Salvia glutinosa, Geranium robertianum, Euphorbia amygdaloides, Veronica officinalis etc. among the most frequent species.

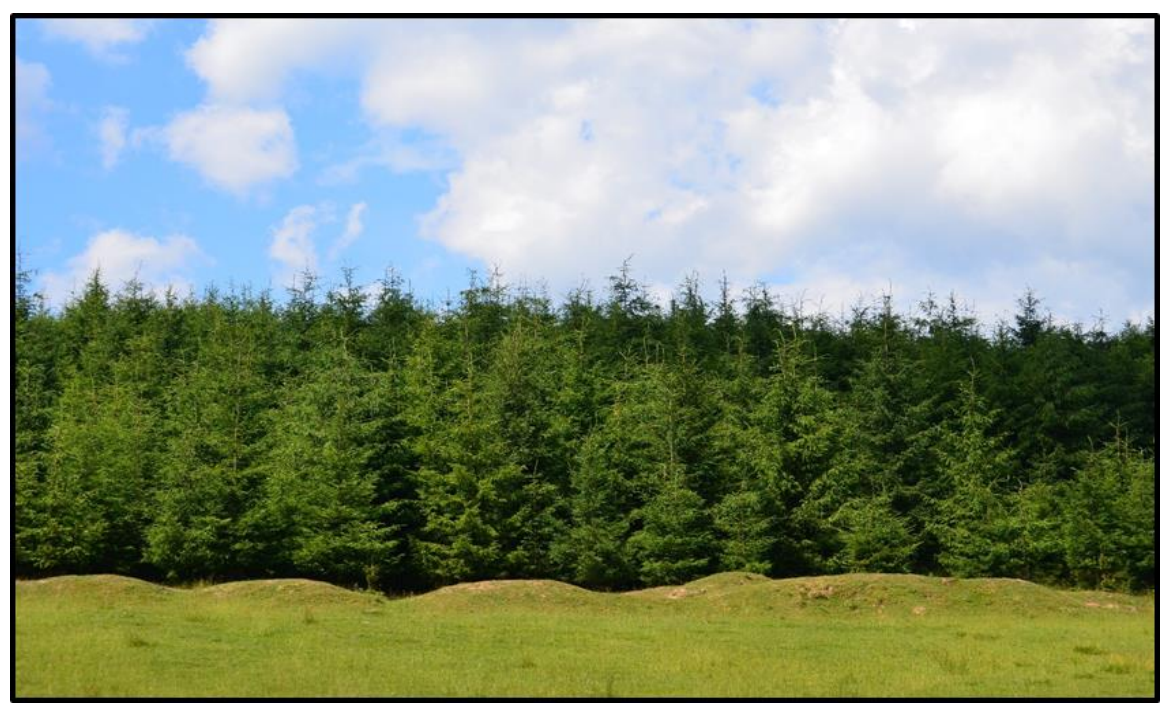

Figure 3. General aspect of the habitat (young Picea abies forest) where Choiromyces meandriformis was identified (Photo C. Bîrsan) 
Table 2. Phytosociological table of Hieracio transsivanici-Piceetum Pawl. et Br.-Bl. 1939 forest communities where the specimens of Choiromyces meandriformis were identified

\begin{tabular}{|c|c|c|c|c|c|c|c|c|}
\hline No. of relevé & 1 & 2 & 3 & 4 & 5 & 6 & 7 & \\
\hline Altitude (m a.s.1.) & 1050 & 1040 & 1000 & 1050 & 1040 & 500 & 510 & \multirow{7}{*}{$\mathbf{K}$} \\
\hline Aspect & NW & NW & NW & NW & NW & $\mathrm{E}$ & $\mathrm{E}$ & \\
\hline Slope $\left({ }^{\circ}\right)$ & 7 & 10 & 7 & 8 & 10 & 5 & 3 & \\
\hline Trees cover $(\%)$ & 90 & 90 & 85 & 90 & 90 & 95 & 90 & \\
\hline Shrubs cover $(\%)$ & 5 & 3 & 3 & 5 & 3 & 5 & 3 & \\
\hline Herbs cover $(\%)$ & 2 & 5 & 10 & 10 & 5 & 5 & 10 & \\
\hline Plot area $\left(\mathrm{m}^{2}\right)$ & 500 & 500 & 500 & 500 & 500 & 1000 & 1000 & \\
\hline \multicolumn{9}{|c|}{ Car. ass. } \\
\hline Picea abies & 5 & 5 & 5 & 5 & 5 & 5 & 5 & $\mathrm{~V}$ \\
\hline Picea abies (juv.) & 1 & - & + & + & + & + & - & IV \\
\hline Hieracium transsilvanicum & - & + & - & - & + & - & - & II \\
\hline \multicolumn{9}{|c|}{ Vaccinio-Piceetea } \\
\hline Luzula luzuloides & + & + & - & + & + & - & - & IV \\
\hline Oxalis acetosella & + & + & + & + & + & - & - & IV \\
\hline Melampyrum sylvaticum & - & + & + & - & + & - & - & III \\
\hline Luzula sylvatica & - & - & + & + & + & - & - & III \\
\hline Calamagrostis arundinacea & - & + & + & - & - & - & - & II \\
\hline Sorbus aucuparia & - & + & - & - & + & - & - & II \\
\hline Sorbus aucuparia (juv.) & - & - & - & - & + & - & - & I \\
\hline Juniperus communis & - & + & - & - & - & - & - & I \\
\hline Campanula abietina & - & - & + & - & - & - & - & I \\
\hline \multicolumn{9}{|c|}{ Querco-Fagetea } \\
\hline Fagus sylvatica & - & + & + & - & - & + & + & IV \\
\hline Fagus sylvatica (juv.) & + & - & + & + & - & + & + & IV \\
\hline Geranium robertianum & - & - & + & + & - & + & + & IV \\
\hline Spiraea chamaedryfolia & + & - & + & + & - & + & - & IV \\
\hline Daphne mezereum & - & + & + & - & + & + & - & IV \\
\hline Euphorbia amygdaloides & - & + & - & - & + & + & + & IV \\
\hline Pulmonaria rubra & - & + & + & - & - & - & + & III \\
\hline Salvia glutinosa & - & - & - & + & - & + & + & III \\
\hline Veronica urticifolia & - & - & + & + & + & - & - & III \\
\hline Corylus avellana & - & + & - & - & - & + & + & III \\
\hline Dryopteris filix-mas & - & - & + & + & + & - & - & III \\
\hline Mycelis muralis & - & - & - & + & - & + & + & III \\
\hline Poa nemoralis & - & - & - & - & - & + & + & II \\
\hline Acer platanoides (juv.) & - & - & - & - & - & + & + & II \\
\hline Epilobium montanum & - & - & - & + & - & - & - & I \\
\hline Lonicera xylosteum & - & - & - & + & - & - & - & I \\
\hline Brachypodium sylvaticum & - & - & - & - & - & - & + & I \\
\hline Glechoma hirsuta & - & - & - & - & - & - & + & I \\
\hline Carex sylvatica & - & - & - & - & - & + & - & I \\
\hline \multicolumn{9}{|c|}{ Epilobietea angustifolii } \\
\hline Fragaria vesca & - & + & - & + & - & + & + & IV \\
\hline Galeopsis speciosa & - & - & + & - & - & - & - & I \\
\hline Betula pendula & - & - & + & - & - & - & - & I \\
\hline Silene dioica & - & - & - & + & - & - & - & I \\
\hline Tussilago farfara & - & - & - & - & - & - & + & I \\
\hline
\end{tabular}


Ciprian BÎRSAN \& al.

\begin{tabular}{lcccccccc}
\hline Digitalis grandiflora & - & - & + & - & - & - & - & I \\
Veronica officinalis & + & - & - & - & + & + & + & IV \\
Urtica dioica & - & - & - & + & + & - & - & II \\
Acer pseudoplatanus & - & - & - & + & - & + & - & II \\
Geum urbanum & - & - & + & - & - & + & - & II \\
Tilia cordata (juv.) & - & - & - & - & + & - & - & I \\
Populus tremula (juv.) & + & - & - & - & - & - & - & I \\
Prunella vulgaris & - & - & - & - & - & - & + & I \\
Pulmonaria officinalis & - & - & - & - & - & - & + & I \\
\hline
\end{tabular}

Place and date of relevés: Izvoarele Sucevei: 10.07.2014 (rel. 1-5);

Capu Câmpului: 12.07.2013 (rel. 6-7).

In a phytosociological perspective, increased constancy presented the diagnostic species for Piceion alliance, Piceetalia order and Vaccinio - Piceetea class (Melampyrum sylvaticum, Luzula luzuloides, Oxalis acetosella, Sorbus aucuparia etc.). Also, the floristic composition included some diagnostic species for Querco - Fagetea (Daphne mezereum, Corylus avellana, Dryopteris filix-mas etc.) and Epilobietea angustifolii (Galeopsis speciosa, Fragaria vesca etc.) classes. Most of the plant species were sciophytes, preferring the cool mountain areas or temperate sub-mountain areas with moderate humid, acid and nutrient poor soils. Canopy closure in investigated areas was high, maintaining soil moisture by not directly exposing it to sunlight. Rainfall and soil moisture were very important in investigated habitats for development of porcine truffle sporocarps.

\section{Conclusions}

This study presented new localities and highlighted similarities with other findings regarding the ecological requirements of the species Choiromyces meandriformis. This species produced hypogeous sporocarps in summer and autumn, in moderate acid and moist soils in some spruce forests from northern part of Romania. Unlike other truffle species, Choiromyces meandriformis was much more easily to be identified because a part of their sporocarps came to the surface without the need for dogs or other animals specially trained to find them. According to the Romanian literature, this species is edible with caution, while in other countries it is considered as toxic species, producing gastrointestinal disorders.

\section{Notes on contributors}

Ciprian BÎRSAN is a PhD biologist at the "Anastasie Fătu" Botanical Garden of Iași, with a special interest for mycology and fungi ecology. His work focuses on the taxonomy, ecology, chorology and diversity of fungal species in Romania.

Constantin MARDARI is a PhD biologist at the "Anastasie Fătu" Botanical Garden of Iași, with a special interest for plant species diversity and also for phytosociology. His work is mainly focused on the diversity, ecology, chorology of plant species and vegetation of Romania.

Cătălin TĂNASE is a Professor PhD at the Faculty of Biology of "Alexandru Ioan Cuza" University from Iași, with a special interest in fungi taxonomy and ecology, phytopathology and isolation and selection of fungi species used in bioremediation and ecological reconstruction of habitats disturbed by human economic activities. 


\section{References}

ASTIER J. 1998. Truffes blanches et noires. In: Bulletin mensuel de la Société Linnéenne de Lyon. 68(10): 1-298.

BEUG M., BESSETTE A. E. \& BESSETTE A. R. 2014. Ascomycete fungi of North America: a mushroom reference guide. Austin: University of Texas Press, $77 \mathrm{pp}$.

BORZA A. \& BOŞCAIU N. 1965. Introducere în studiul covorului vegetal. Bucureşti: Edit. Acad. Române, 294 pp.

BRAUN-BLANQUET J. 1964. Pflanzensoziologie. Grundzüge der Vegetationskunde. $3^{\text {rd }}$ Edition. Wien: Springer Verlag, $865 \mathrm{pp}$.

BRESSON Y. 1996. Dictionnaire étimologiques des noms scientifiques des champignons, Aix-en-Provence: Muséum d' Histoire Naturelle d' Aix-en-Provence, 237 pp.

CALONGE F. D., DE LA TORRE M. \& LAWRYNOWICZ M. 1977. Contribución al estudio de los hongos hipogeos de España. Anales del Instituto Botánico Cavanilles. 34(1): 15-31.

COURTECUISSE R. \& DUHEM B. 2013. Guide des Champignons de France et d'Europe. Lausanne: Edit. Delachaux \& Niestlé: 544 pp.

FOURRÉ G. 2000. Les champignons hypogés du Centre-Ouest de la France. Bulletin Semestriel de la Fédération des Associations Mycologiques Méditerranéennes. 18: 69-80.

GERHARDT E. 1999. Guide Vigot des champignons. Vigot Maloine: 664 pp.

GYOSHEVA M. M., DENCHEV C. M., DIMITROVA E. G., ASSYOV B., PETROVA R. D. \& STOICHEV G. T. 2006. Red List of Fungi in Bulgaria. Mycologia Balcanica. 3: 81-87.

HALAMA M. \& PALEK E. 2000. Macromycetes of various habitats of the nature reserve "Lezczok" near Raciborz (SW Poland). Acta Mycologica. 35(2): 217-241.

HOBART C. 2005. A truffler's talle. Field Mycology. 6(4): 124-126.

KUTORGA E. \& KATARŽYTÉ M. 2008. Hypogeous fungi of Lithuania: a preliminary checklist. Acta Mycologica. 43(2): 133-138.

LACHEVA M. 2012. New records for hypogeous ascomycetes in Bulgaria. Science \& Technologies. 2(6): 30-34.

MORENO G., ALVARADO P. \& MANJÓN J. L. 2011. Phylogenetic affiliation of Choiromyces magnusii and $C$. venosus (Tuberaceae, Ascomycota) from Spain. Mycological Progress. 11(2): 463-471.

NEGREAN G. \& DRĂGULESCU C. 2005. Mycobiota judetului Sibiu [in Romanian]. Sibiu: Edit. Univ. „Lucian Blaga", $358 \mathrm{pp}$.

PAP G., PAZMANY D. \& MISKY M. 1983. New data regarding hypogeous mushrooms of Romania. Notulae Botanicae Horti Agrobotanici. 13(1): 29-38

PÁZMÁNY D. 1990-1991. Conspectus Fungorum Hypogaeorum Transsilvanyae. Notulae Botanicae Horti Agrobotanici. 20-21: 28.

RODRIGEZ A. 2008. The false truffles. http://www.trufamania.com

SĂLĂGEANU G. \& SĂLĂGEANU A. 1985. Determinator pentru recunoasterea ciupercilor comestibile, necomestibile si otravitoare din România [in Romanian]. Bucureşti: Edit. Ceres, 331 pp.

SIERRA D., MARTÍN M. P. \& LLIMONA X. 1991. Noves dades sobre fongs hipogeus. I: Ascomicets. Butlleti de la Societat Catalana de Micologia. 14-15: 43-66.

TRAPPE J. M. \& CASTELlANO M. A. 2007. Keys to the genera of trufles (Ascomycetes). Available at: http://www.natruffling.org/ascokey.htm.

TÜRKOĞLU A. \& CASTELLANO M. A. 2014. New records of some Ascomycete truffle fungi from Turkey. Turkish Journal of Botany. 38: 406-416.

VENTURElla G., ALTOBElli E., BERNiCCHIA A., Di PIAZZA S., DONNINI D., GARGANO M. L., GORJÒN S. P., GRANITO V. M., LANTIERI A., LUNGHINI D., MONTEMARTINI A., PADOVAN F., PAVARINO M., PECORARO L., PERINI C., RANA G., RIPA C., SALERNI E., SAVINO E., TOMEI P. E., VIZZINI A., ZAMBONELLI A. \& ZOTTI M. 2011. Fungal biodiversity and in situ conservation in Italy. Plant Biosystems. 145(4): 950-957.

WEDEN C., SONNY L., BURMAN R. \& BACKLUND A. 2009. The edible truffle Choiromyces venosus and its use in Sweden. Acta Botanica Yunnanica. 26 (supplement): 94-96.

*** www.indexfungorum.org.

How to cite this article:

BÎRSAN C., MARDARI C. \& TĂNASE C. 2019. New localities and habitat conditions for Choiromyces meandriformis Vitt. (Ascomycota, Fungi) in Northern Romania. J. Plant Develop. 26: 173-180. https://doi.org/10.33628/jpd.2019.26.1.173 